\title{
Sensibility of Plant Species to Herbicides AMINOCYCLOPYRACHLOR AND INDAZIFLAM ${ }^{1}$
}

\author{
Sensibilidade de Espécies Vegetais aos Herbicidas Aminocyclopyrachlor e Indaziflam
}

GUERRA, N. ${ }^{2}$, OLIVEIRA NETO, A.M. ${ }^{2}$, OLIVEIRA JR, R.S. ${ }^{2}$, CONSTANTIN, J. $^{2}$, and TAKANO, H.K. ${ }^{2}$

\begin{abstract}
Aminocyclopyrachlor and indaziflam are under development in Brazil and there is no information about their behavior in Brazilian soils. This study aimed to evaluate the sensitivity of plant species to these new molecules, trying to select plants that can be used as bioindicators for testing the behavior of these herbicides in the soil. Two experiments were conducted, one for each herbicide. The treatments were arranged in a $8 \times 6$ factorial design, the factors being represented by eight species used as bioindicators - cotton, maize, soybean, sorghum, sunflower, millet, cucumber and beet, and six doses of herbicides (aminocyclopyrachlor - 0, 10 , 20, 30 , 40 and $50 \mathrm{~g} \mathrm{ha}^{-1}$ and indaziflam 0 , 20, 40 , 60, 80 and $\left.100 \mathrm{~g} \mathrm{ha}^{-1}\right)$. Among the species studied, soybean and beet were quite sensitive to the two new herbicide molecules, being great alternatives for bioassays in order to detect low concentrations of aminocyclopyrachlor and indaziflam in the soil.
\end{abstract}

Keywords: beet, bioassay, $\mathrm{I}_{50}$, soybean.

RESUMO - O aminocyclopyrachlor e indaziflam encontram-se em fase de desenvolvimento no Brasil e não existem informações a respeito do comportamento destes em solos brasileiros. Este trabalho teve como objetivo avaliar a sensibilidade de espécies vegetais à estas novas moléculas, buscando selecionar plantas que possam ser utilizadas como bioindicadores em ensaios de comportamento destes herbicidas no solo. Foram conduzidos dois experimentos um para cada herbicida. Os tratamentos foram dispostos em esquema fatorial $8 \times 6$, sendo os fatores representados por oito espécies utilizadas como bioindicadoras - algodão, milho, soja, sorgo, girassol, milheto, pepino e beterraba e seis doses dos herbicidas (aminocyclopyrachlor-0; 10; 20; 30; 40 e $50 \mathrm{~g} \mathrm{ha}^{-1}$ e indaziflam 0; 20; 40; 60; 80 e $100 \mathrm{~g} \mathrm{ha}^{-1}$ ). Dentre as espécies estudadas a soja e a beterraba mostraram-se bastante sensiveis as duas novas moléculas herbicidas, sendo ótimas alternativas para bioensaios visando a detecção biológica de baixas concentrações de aminocyclopyrachlor e indaziflam no solo.

Palavras-chave: beterraba, bioensaio, $\mathrm{I}_{50}$, soja.

\section{INTRODUCTION}

Aminocyclopyrachlor and indaziflam are new herbicide molecules that are under development in Brazil. The former for the sugar cane culture and pasture and the latter for the sugar cane culture.

Aminocyclopyrachlor (6-amino-5-chloro-2cyclopropyl-4-pyrimidinecarboxylic acid) is an auxin mimic herbicide, from the chemical group of pyrimidinecarboxylic acids. In the United States, it is registered for weed control in pastures and non-agricultural areas, including lawns, airports, highways, railroads, recreation areas etc. This herbicide presents both foliar and residual activity (Turner et al., 2009; McCloskey et al., 2011) and a broad spectrum of weed control (Rick et al, 2008).

Recebido para publicação em 31.10.2013 e aprovado em 27.4.2014.

2 Universidade Estadual de Maringá, Maringá-PR, Brazil, <naiaraguerra.ng@gmail.com>. 
It has low toxicity to mammals and wild animals, exhibiting favorable environmental profile due to the doses used and the broad spectrum of control. Typical of auxinic herbicides, aminocyclopyrachlor is translocated systemically (Bukun et al., 2010), but it is effective in much lower doses than other auxinic herbicides such as 2,4 D (Turner et al., 2009). Studies conducted in a greenhouse by Strachan et al. (2011) showed that the species of the class Liliopsida have increased tolerance to aminocyclopyrachlor applied to the soil than species of the class Magnoliopsida. Studies conducted by Oliveira Jr. et al. (2011) in Brazilian and American soils show that on the basis of sorption of aminocyclopyrachlor this can be very mobile in the soil.

Indaziflam $(\mathrm{N}-[(1 \mathrm{R}, 2 \mathrm{~S})-2,3-$ dihidro-2,6dimetil-1H-inden-1-il]-6-[(1R)-1-fluoroetilo]1,3,5-triazina-2,4-diamina) inhibits cellulose biosynthesis in susceptible plants, and belongs to the chemical group alkylazine (Myers et al., 2009). The first registration of indaziflam was in 2010, in the United States, for use on lawns (Kaapro \& Hall, 2012). In Canada, it is registered for controlling weeds in Liliopsida and Magnoliopsida families in areas cultivated with fruit trees such as apples, pear, citrus, grapes, and nuts (Bayer, 2012). It has pre- and early-post emergence activity on weeds. Prolonged residual activity is one of its main features; Brosnan et al. (2012), for example, verified an excellent control of Poa annua, even 28 weeks after application. Myers \& Parker (2011) also noted a long period of residual activity (between three and five months) for species like Eclipta alba, Euphorbia maculata and Senecio vulgaris. Alonso et al. (2011) found a positive correlation between the sorption indaziflam and organic carbon content of several Brazilian soils, and classified this herbicide as moderate potential for leaching in the soil profile.

As these herbicides are being developed in Brazil, there is no information about their behavior on our soils. Thus, the present study aimed to evaluate the sensitivity of plant species to new herbicide molecules aminocyclopyrachlor and indaziflam, seeking to select plants that can be used as bioindicators in behavior trials of these herbicides on the soil.

\section{MATERIAL AND METHODS}

The experiments were conducted during the months of December 2011 and January 2012 , in a greenhouse. The soil used as substrate had a sandy clay loam texture $169 \%$ sand; $29 \%$ clay and $2 \%$ silt), and the following chemical characteristics: $\mathrm{pH}\left(\mathrm{H}_{2} \mathrm{O}\right)$ of 5.9; $3.68 \mathrm{cmol}_{\mathrm{c}} \mathrm{dm}^{-3} \mathrm{H}^{+}+\mathrm{Al}^{3+} ; 3.17 \mathrm{cmol}_{\mathrm{c}} \mathrm{dm}^{-3}$ of $\mathrm{Ca}^{+2}$; $0.67 \mathrm{cmol}_{\mathrm{c}} \mathrm{dm}^{-3}$ of $\mathrm{Mg}^{+2} ; 0.61 \mathrm{cmol}_{\mathrm{c}} \mathrm{dm}^{-3}$ of $\mathrm{K}^{+}$; $47.6 \mathrm{mg} \mathrm{dm}^{-3}$ of $\mathrm{P}$ and $11.89 \mathrm{~g} \mathrm{dm}^{-3}$ of $\mathrm{C}$.

Experiments were conducted simultaneously for the herbicides aminocyclopyrachlor and indaziflam. The treatments were arranged in a $8 \times 6$ factorial design, with the factors being represented by eight species used as bioindicators - cotton cv. FMT $707^{\circledR}$ (Gossypium hirsutum); hybrid maize DKB $3904^{\circledR}$ (Zea mays); soybean cv. V $\max ^{\circledR}$ (Glycine max); hybrid sorghum BRS $306^{\circledR} \quad$ (Sorghum bicolor); sunflower cv. BRS $321^{\circledR}$ (Helianthus annus); millet cv. BRS $1501^{\circledR}$ (Pennisetum glaucum); cucumber cv. Safira ${ }^{\circledR}$ (Cucumis sativus) and beets cv. All Green ${ }^{\circledR}$ (Beta vulgaris esculenta) and six doses of the herbicides (aminocyclopyrachlor - 0;10;20;30; 40 and $50 \mathrm{~g} \mathrm{ha}^{-1}$ and indaziflam $0 ; 20 ; 40 ; 60 ; 80$ and $100 \mathrm{~g} \mathrm{ha}^{-1}$ ). The experimental design for both trials was completely randomized, with four replications.

The experimental units were composed of polyethylene pots with a capacity of $3 \mathrm{dm}^{3}$ of soil, in which five seeds of each species were sown at a depth of 1-2 cm. After sowing, the pots were irrigated and after two hours we proceeded to the application of herbicides. The application was held on $15 / 12 / 2011$, with a $\mathrm{CO}_{2}$ pressure backpack sprayer, equipped with four tips XR110.02 maintained at the working pressure of $2 \mathrm{kgf} \mathrm{cm}^{-2}$, which resulted in a spray volume of $200 \mathrm{~L} \mathrm{ha}^{-1}$. At the time of application, the air temperature was $28.8^{\circ} \mathrm{C}$ and relative humidity was $35.1 \%$, with winds of $1.8 \mathrm{~km} \mathrm{~h}^{-1}$.

After 21 days after application (DAA) of the herbicides, the number of live plants per pot was counted, then their shoot were collected. This material was weighed on a precision scale in order to obtain the fresh weight of shoots.

The results of the fresh weight of the shoots of the bioindicators were subjected to 
analysis of variance $(\mathrm{p} \leq 0.05)$ and regression. Regression models were chosen considering the significance of the regression coefficients and biological significance. Based on the data and regression models, we established the $I_{50}$ (dose required for $50 \%$ reduction of fresh weight) in order to compare the sensitivity of the species.

The regression models used in this work were:

Linear Model: Represented by the equation $\mathrm{Y}=\mathrm{A}+\left(-\mathrm{B}^{*} \mathrm{X}\right)$, where $\mathrm{Y}$ is the estimate of the variable in question, $A$ is the maximum fresh weight, B is the rate of decline of the analyzed variable and $\mathrm{X}$ is the herbicide dose.

Hyperbole Model: It is represented by the equation $\mathrm{Y}=\left(\mathrm{A}^{*} \mathrm{~B}\right) /(\mathrm{B}+\mathrm{X})$, where $\mathrm{Y}$ is the estimate of the variable in question, $X$ is the herbicide dose, $\mathrm{A}$ is the maximum fresh weight and $\mathrm{B}$ are the model's nonlinear regression parameters.

Sigmoidal model (3 parameters): It is represented by the equation $\mathrm{Y}=\mathrm{A} / 1+\exp -[(\mathrm{X}-$ $\mathrm{Xo} / \mathrm{B}]$, where $\mathrm{Y}$ is the estimate of the variable in question, $\mathrm{X}$ is the herbicide dose, $\mathrm{A}$ is the maximum fresh weight and $B$ are the model's nonlinear regression parameters, Xo is the dose required for $50 \%$ reduction of parameter A.

Sigmoidal Model (4 parameters): It is represented by the equation $\mathrm{Y}=\mathrm{Yo}+\mathrm{A} / 1+\mathrm{exp}-$ $[(\mathrm{X}-\mathrm{Xo}) / \mathrm{B}]$, where $\mathrm{Y}$ is the estimate of the variable in question, $\mathrm{X}$ is the dose of herbicide $\mathrm{A}$ and $\mathrm{B}$ are the model's nonlinear regression parameters; Xo is the initial dose or $0 \mathrm{~g} \mathrm{ha}^{-1}$ of the herbicide; Yo is the fresh weight obtained with the initial dose.

\section{RESULTS AND DISCUSSION}

The Liliopsida cultures were more tolerant to aminocyclopyrachlor compared to Magnoliopsida. Maize, sorghum and millet suffered no visual damage (Figure 2), so that there was no reduction in fresh weight (Figure 1) when these bioindicators were sown on soil treated with this herbicide. Thus, the $I_{50}$ value of these crops was higher than the highest dose tested (> $50 \mathrm{~g} \mathrm{ha}^{-1}$ ) (Table 1).
Strachan et al. $(2010,2011)$ also tested the sensitivity of various species to aminocyclopyrachlor and found that none of the Liliopsida species were sensitive to this herbicide, so that even the soil application of $64 \mathrm{~g} \mathrm{ha}^{-1}$ of the product was sufficient to reach values of $\mathrm{I}_{25}(25 \%$ reduction in dry weight compared to the control treatment). Maize, oats, wheat, rye and barley were among the tested species. These species are tolerant of most auxin mimic herbicides, and the selectivity is related to several factors, such as arrangement of vascular tissue in bundles, presence of intercalary meristems, metabolism and exsudation through the root system. The movement of auxins in these species is more restricted, with degradation and metabolization occurring more sharply (Flessner et al., 2011) which leads to lower arrival of these products in places where they act, that is, the growing meristems in young seedlings of plants. However, the results of Kniss \& Lyon (2011) demonstrated that although wheat planted 15 days after application of $20 \mathrm{~g} \mathrm{ha}^{-1}$ aminocyclopyrachlor did not present crop visual symptoms of intoxication at harvest, there was a reduction of $50 \%$ in grain yield. This result was justified by the fact that the use of auxin mimics induces parthenocarpy (production of seedless fruits). According to Gillaspy et al. (1993) increased levels of auxin in ovule or ovaries will cause the initiation of fruit development without fertilization. This would prevent the production of grains in a normal-looking wheat plant (Kniss \& Lyon, 2011).

Table 1 - $\mathrm{I}_{50} \frac{1 /}{}$ values for different species after application of aminocyclopyrachlor and indaziflam

\begin{tabular}{|l|c|c|}
\hline \multirow{2}{*}{ Species } & \multicolumn{2}{|c|}{$\mathrm{I}_{50}\left(\mathrm{~g} \mathrm{ha}^{-1}\right)$} \\
\cline { 2 - 3 } & Aminocyclopyrachlor & Indaziflam \\
\hline Cotton & 9.70 & 63.50 \\
\hline Maize & $>50.00$ & 86.00 \\
\hline Soybean & 2.55 & 1.80 \\
\hline Sorghum & $>50.00$ & 0.50 \\
\hline Sunflower & 24.50 & $>100.00$ \\
\hline Millet & $>50.00$ & 3.60 \\
\hline Cucumber & 39.50 & 2.30 \\
\hline Beet & 0.65 & 2.90 \\
\hline
\end{tabular}

$1 /$ Dose of the herbicide required to cause $50 \%$ reduction in fresh weight of the bioindicators in relation to the control without herbicide. 

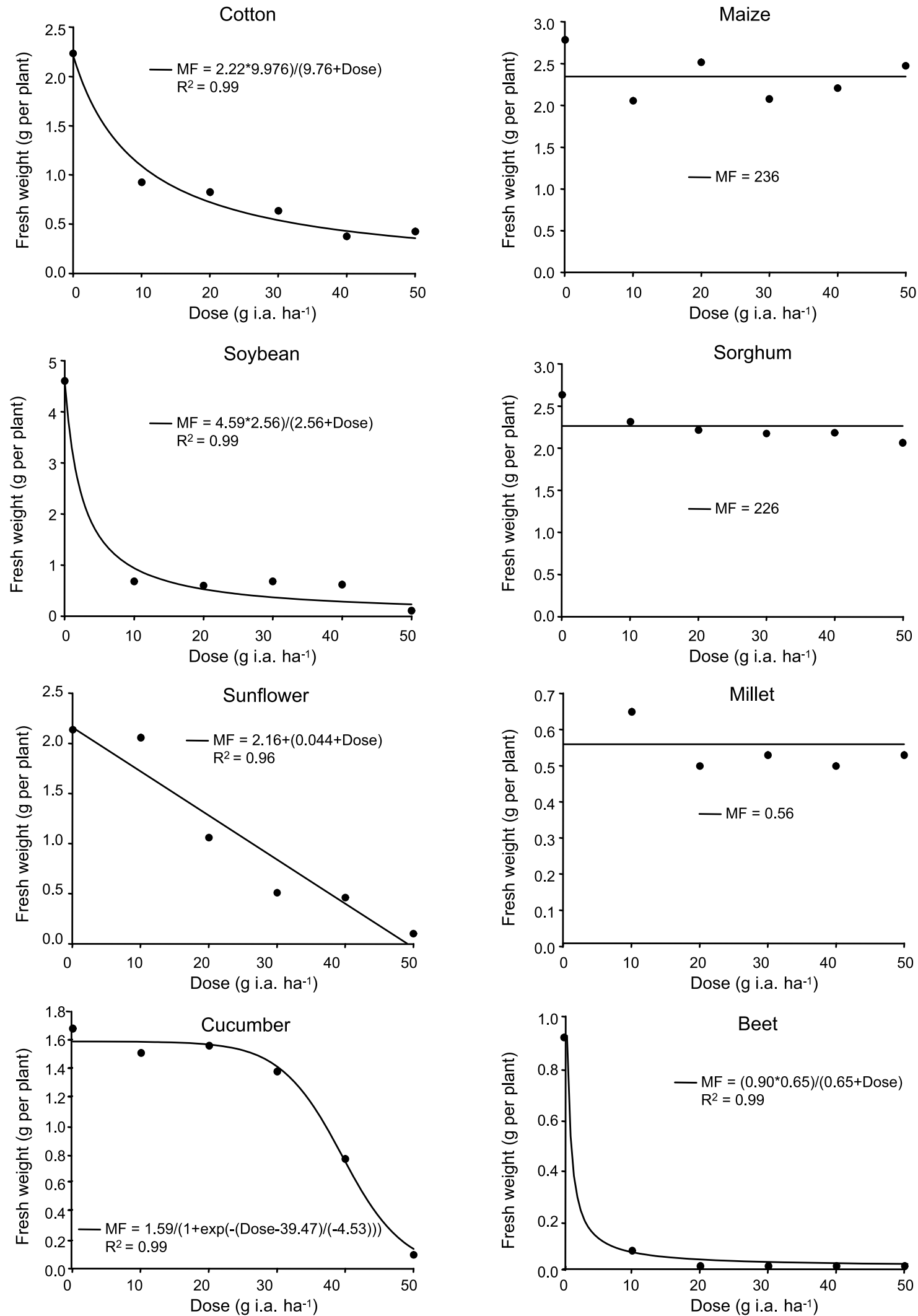

Figure 1 - Effect of doses of aminocyclopyrachlor on the fresh weight of shoots of plant species. 

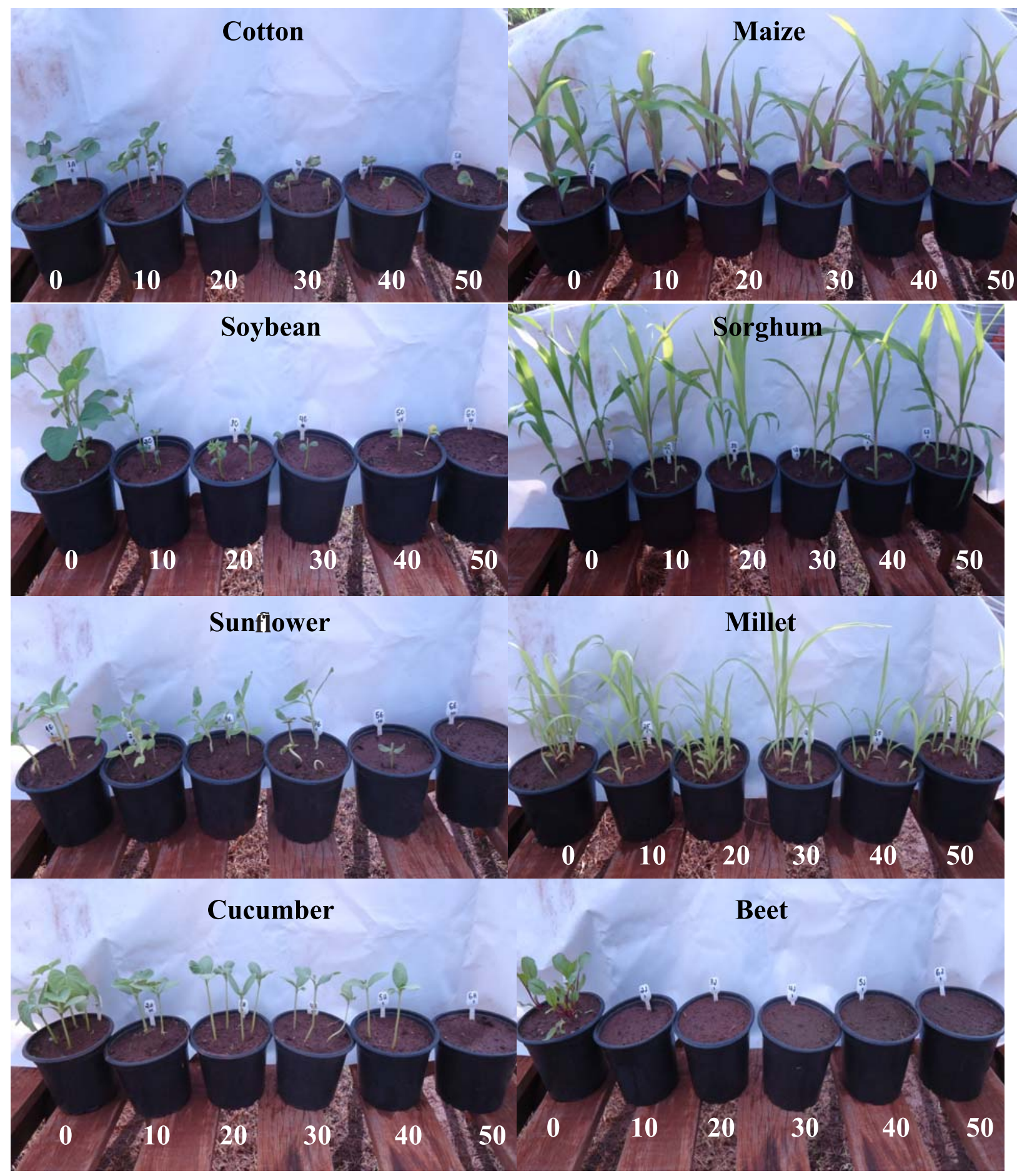

Figure 2 - Visual symptoms of intoxication in species after application of different doses ( $\left.\mathrm{g} \mathrm{ha}^{-1}\right)$ of aminocyclopyrachlor.

Symptoms of intoxication observed in cotton, soybean, sunflower and cucumber were characterized by epinasty and curling leaves, stems and petioles. According to Strachan et al. (2010) these intoxication symptoms in Magnoliopsida species are similar to those observed when applying the herbicide aminopyralid, which also has the same mechamism of action. For beets, seedling emergence was verified, however, plants died 
even in the same soil with the lowest dose of aminocyclopyrachlor (10 $\left.\mathrm{g} \mathrm{ha}^{-1}\right)$ (Figure 2).

The $I_{50}$ values for Magnoliopsida species varied between 0.65 and $39.50 \mathrm{~g} \mathrm{ha}^{-1}$. Among these species, the one which showed the highest tolerance to aminocyclopyrachlor was cucumber with an $I_{50}$ of 39.50 . Then, sunflower and cotton, with $\mathrm{I}_{50}$ of 24.50 and 9.70, respectively. The most sensitive species were soybeans and beets. For the first, it was noted that the dose of only $2.55 \mathrm{~g} \mathrm{ha}^{-1}$ was sufficient to cause a $50 \%$ reduction in fresh weight, and for beet this value was even lower (0.65) (Figure 1 and Table 1).

Strachan et al. (2010) also reported a high sensitivity of soybean to this herbicide, reporting that the dose of $1.0 \mathrm{~g} \mathrm{ha}^{-1}$ was enough to promote $50 \%$ phytotoxicity in this species. The sensitivity of soybean, sunflower (Westra et al, 2008; Strachan et al., 2011), cotton, beet (Strachan et al., 2011) and alfalfa (Westra et al., 2008) to aminocyclopyrachlor has already been described in the literature by other authors.

Strachan et al. (2013) has also reported that soybean is highly sensitive to auxinic herbicides (aminocyclopyrachlor, aminocyclopyrachlor methyl, aminopyralid and dicamba) and used this species as a bioindicator of volatilization of these herbicides.

All species tested were sensitive to indaziflam. The only symptom observed in the different species after planting in soil containing this herbicide was the non emergence of seedlings, except for sunflower. Cotton and maize did not emerge only when sown in the soil with the highest dose of indaziflam (100 $\left.\mathrm{g} \mathrm{ha}^{-1}\right)$. For soybean, there was emergence in the soil treated with the two lower doses (20 and $40 \mathrm{~g} \mathrm{ha}^{-1}$ ), however, these plants died after a few days. While for sorghum, millet, cucumber and beet, there was no emergence even in the soil that received the lowest dose of this herbicide $\left(20 \mathrm{~g} \mathrm{ha}^{-1}\right)$ (Figure 4).

The exact mechanism of action of this herbicide is not yet completely understood. It prevents the formation of the cell wall in new cells, so there is a stoppage of plant growth.
The formation of the cell wall is inhibited, but the synthesis of polysaccharide polymers is not affected. The inhibition probably occurs somewhere in the stage of crosslinking of cellulose microfibrils. The inhibition of cell division of the meristematic tissue has also been proposed as a secondary mode of action (Griffin, 2005). To Kaapro \& Hall (2012), inhibition of crystal deposition on the cell wall, severely affecting their formation, division and cell elongation. This indicates that the fully developed leaves will hardly be affected, or not affected at all, by indaziflam, as long as the cell wall formation has been completed and no new synthesis of cellulose occurs. The efficacy in post-emergence applications has been observed until the 2-leaf stage. According to Griffin (2005), the symptoms observed in susceptible plants grown in soil treated with herbicides of this mechanism of action are characterized by lack of emergence and if there is emergence, root growth is subsequently reduced, causing its death.

Indaziflam belongs to the new chemical class alkylazine, which acts in the biosynthesis of the cell wall and is considered the most potent inhibitor of the cell wall ever discovered (Myers et al., 2009; Kaapro \& Hall, 2012). Among the species tested, the most tolerant to indaziflam was sunflower. This species showed a slight decrease in the fresh weight of shoots, but even the highest dose used (100 $\mathrm{g} \mathrm{ha}^{-1}$ ) did not reach enough injury to achieve $I_{50}$ values. Maize and cotton showed intermediate tolerance to indaziflam, with $\mathrm{I}_{50}$ values of 86.00 and 63.50 respectively. Most species tested showed high sensitivity to indaziflam. Soybean, sorghum, millet, cucumber and beet had $\mathrm{I}_{50}$ values lower than $5 \mathrm{~g} \mathrm{ha}^{-1}$ of indaziflam, which is 20 times lower than the dose commonly used in countries where this herbicide is already registered (Figure 3 and Table 1).

Jhala et al. (2012) performing indaziflam dose-response studies on Lolium multiflorum, found that doses of 3.65 and $14.62 \mathrm{~g} \mathrm{ha}^{-1}$ are sufficient to inhibit germination of the species at 70 and $90 \%$, respectively. Doses greater than $29.2 \mathrm{~g} \mathrm{ha}^{-1}$ completely inhibit the germination of ryegrass.

In this work, it was observed that among the species studied, soybean and beets were 

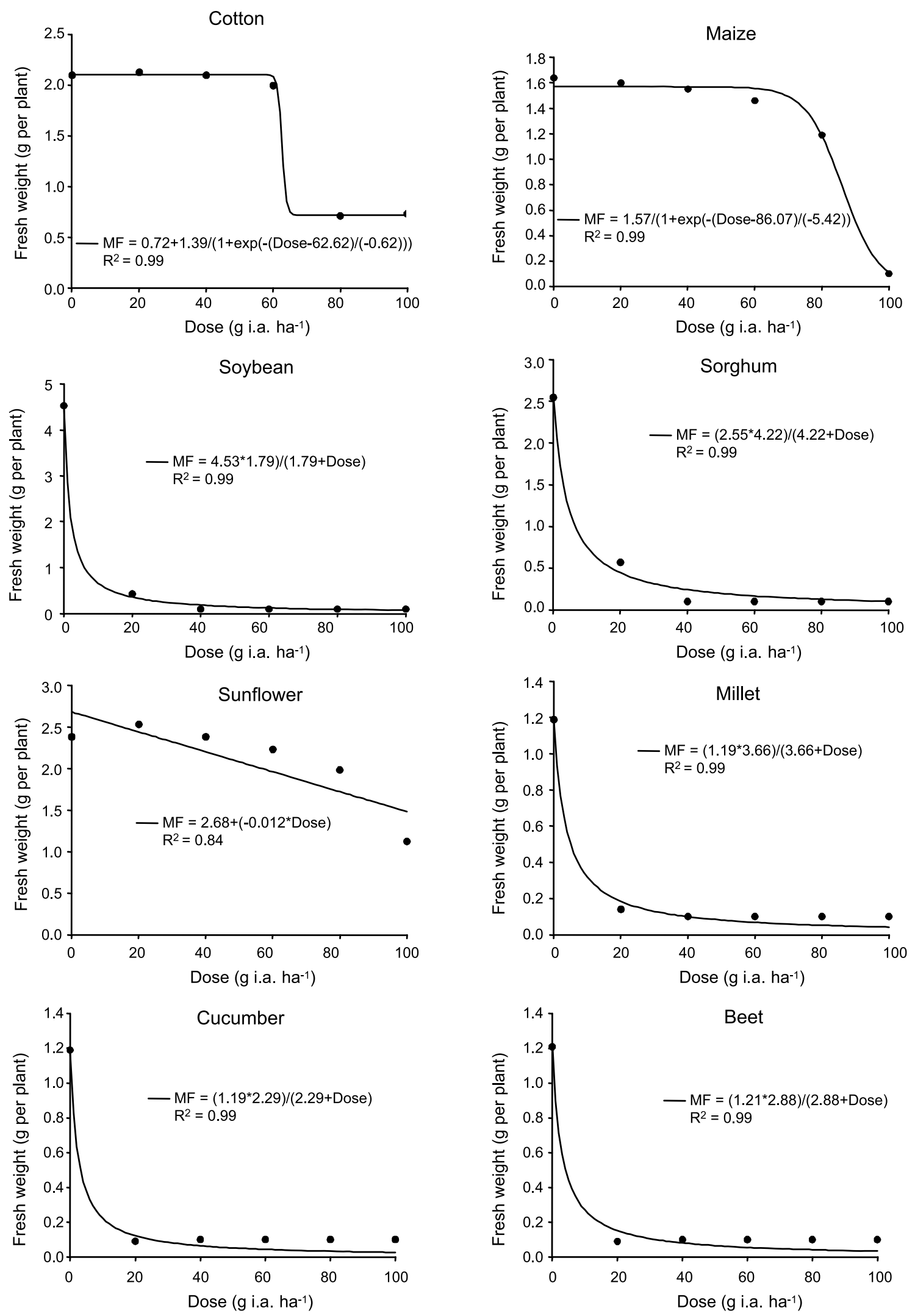

Figure 3 - Effect of doses of indaziflam on the fresh weight of shoots of plant species. 


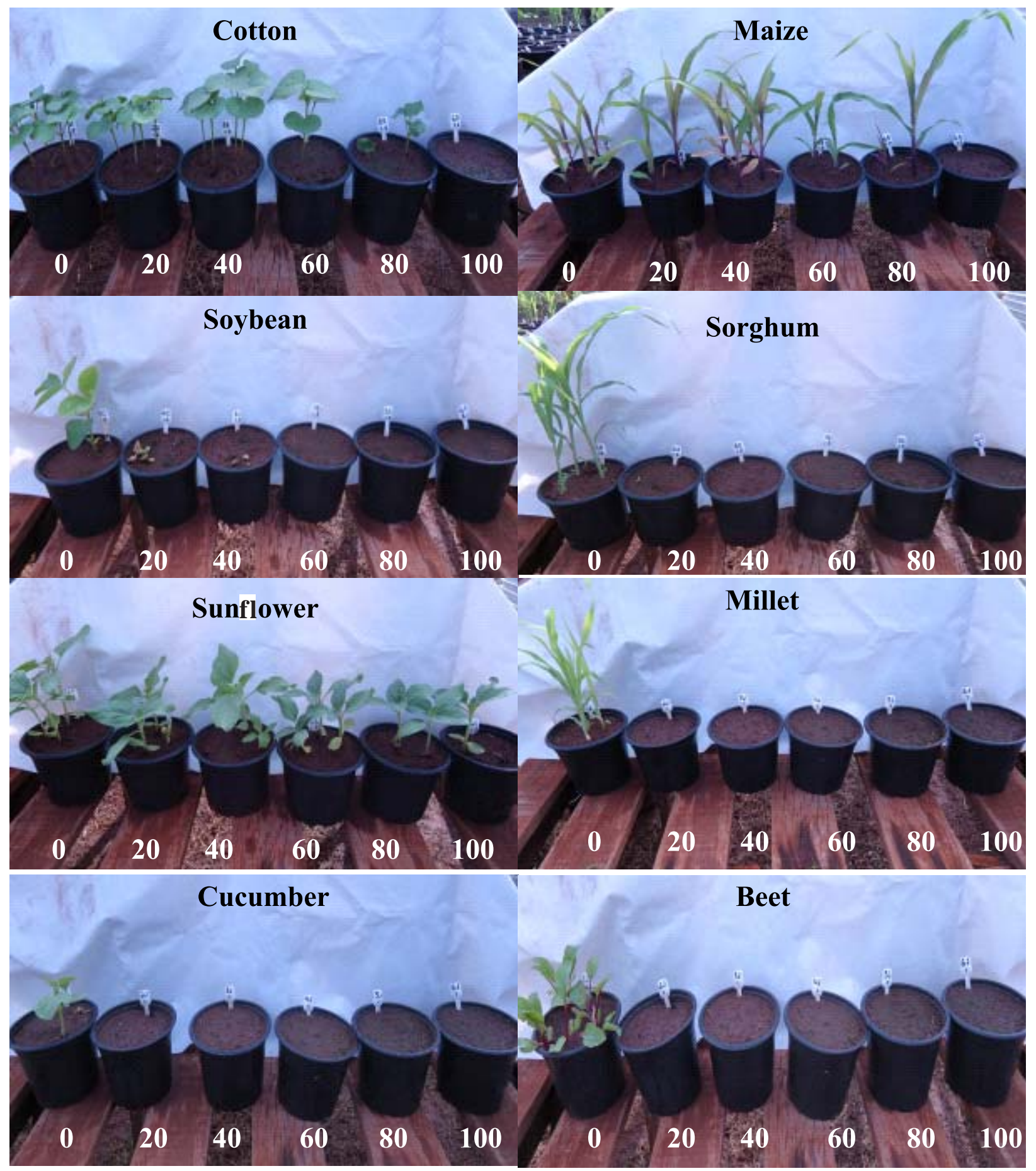

Figure 4 - Visual symptoms of intoxication of plant species after application of different doses (g ha-1) of indaziflam.

quite sensitive to the two new herbicide molecules, being great alternatives to bioassays aimed at the biological detection of low concentrations of aminocyclopyrachlor and indaziflam in the soil.

\section{CITED LITERATURE}

ALONSO, D.G. et al. Sorption-desorption of indaziflam in selected agricultural soils. Journal of Agricultural and Food Chemistry, v.59, n.4, p.3096-3101, 2011. 
BAYER ENVIRONMENTAL SCIENCE. Indaziflam, 2012. 15 p. Disponível em: <http://www.agf.gov.bc.ca/pesticides/ indaziflam\%20500_label.pdf>. Acesso em: 10 set. 2013.

BROSNAN, J. T. et al. Pre and post emergence annual bluegrass control with indaziflam. Weed Technol., v. 26, n. 1, p. 48-53, 2012.

BUKUM, B. et al. Absorption and translocation of aminocyclopyrachlor and aminocyclopyrachlor-methyl ester in Canada thistle (Cirsium arvense). Weed Sci., v. 58, n. 2, p. 96-102, 2010.

FLESSNER, M. L. et al. Anatomical response of St. Augustinegrass to aminocyclopyrachlor tratament. Weed Sci., v. 59, n. 2, p. 263-269, 2011.

GILLASPY, G. et al. Fruits: a developmental perspective. Plant Cell, v. 5, n. 10, p. 1439-1451, 1993.

GRIFFIN, J. L. Inhibition of cell wall synthesis. In: GRIFFIN, J. L. Weed course. 2005, p. 150-153.

JHALA, A. J. et al. Leaching of indaziflam applied of two rates under different rainfall situations in Florida Clandler Soil. Bull. Environ. Contam. Toxicol., v. 88, n. 3, p. 326-332, 2012.

KAAPRO, J.; HALL, J. Indaziflam, a new herbicide for preemergent control of weeds in turf, forestry, industrial vegetation and ornamentals. Pak. J. Weed Sci. Res., v. 18, p. 267-270, 2012. (Número Especial)

KNISS, A. R.; LYON, D. J. Winter wheat response to preplant applications of aminocyclopyrachlor. Weed Technol., v. 25, n. 1, p. 51-57, 2011.

MC CLOSKEY, W. B. et al. Knapweed management in southwestern abandoned pastures. Proc. Weed Sci. Soc. Am. Abstr., v. 49, 2011. Abstract 58. Disponível em: <http:// wssaabstracts.com/public/4/proceedings.html.>. Acesso em: 14 set. 2013.
MYERS, D. F. et al. Indaziflam/BCS AA170717 - a new herbicide for preemergent control of grasses and broadleaves in turf and ornamentals. Proc. South Weed Sci. Soc. Abstr., v. 62, p. 393, 2009.

MYERS, D.; PARKER, A.Weed control and ornamental tolerance to indaziflam. Proc Weed Sci. Soc. Am. Abstr., v.49, 2011. Abstract 58. Disponível em: <http:// wssaabstracts.com/public/4/proceedings.html>. Acesso em: 13 set. 2013.

OLIVEIRA JR., R.S.; ALONSO, D.G.; KOSKINEN, W.C. Sorption-desorption of aminocyclopyrachlor in selected Brazilian soils. Journal of Agricultural and Food Chemistry, v.59, n.8 , p.4045-4050, 2011.

RICK, S. K. et al. Biology review of aminocyclopyrachlor. Proc North Central Weed Sci. Soc. Abstr., v. 63, p. 202, 2008.

STRACHAN, S. D. et al. Vapor movement of synthetic auxin herbicide: Aminocyclopyrachlor, aminocyclopyrachlormethyl ester, dicamba and aminopyralid. Weed Sci., v. 58, n. 2, p. 103-108, 2010.

STRACHAN, S. D. et al. Correlation of chemical analysis of residual levels of aminocyclopyrachlor in soil to biological responses of alfalfa, cotton, soybeanbean, and sunflower. Weed Technol., v. 25, n. 2, p. 239-244, 2011.

STRACHAN, S. D. et al. Vapor movement of aminocyclopyrachlor, aminopyralid and dicamba in the field. Weed Technol., v. 27, n. 1, p. 143-155, 2013.

TURNER, R. G. et al. Technical introduction of the new DuPont vegetation management herbicide aminocyclopyrachlor. Proc. South Weed Sci. Soc. Abstr., v. 62, p. 405, 2009.

WESTRA, P. et al. Agronomic crop responses to KJM-44 herbicide. Proc. North Central Weed Sci. Soc., v. 63, p. 61-62, 2008. 